\title{
EFISIENSI BIAYA PRODUKSI PUPUK ORGANIK BERBAHAN DASAR LIMBAH MEDIA BUDIDAYA LALAT TENTARA HITAM (Hermetia illucens)
}

\section{PRODUCTION COST EFFICIENCY OF ORGANIC FERTILIZER BASED ON WASTE MEDIA CULTIVATION OF BLACK SOLDIER FLY (Hermetia illucens)}

\author{
Nurul Risti Mutiarasari*, Yogi Nirwanto \\ Fakultas Pertanian Universitas Siliwangi, Tasikmalaya \\ *E-mail corresponding: nurulristim@unsil.ac.id \\ (Diterima 07-12-2021; Disetujui 22-01-2022)
}

\begin{abstract}
ABSTRAK
Ketersediaan limbah organik yang melimpah menjadi daya tarik masyarakat sebagai peluang usaha pemanfaatan limbah organik. Salah satu pemanfaatan limbah organik yang dilakukan adalah sebagai media tumbuh serta pakan dalam budidaya lalat tentara hitam (Black Soldier Fly/BSF) atau pakan maggot yang pada akhir periodenya terdapat sisa media budidaya berupa bahan organik yang berpotensi dijadikan sebagai bahan pupuk organik. Pupuk organik menjadi salah satu alternatif pemanfaatan limbah organik yang dapat dihasilkan dari sisa media budidaya lalat tentara hitam (BSF). Tujuan penelitian ini adalah untuk mengukur harga pokok produksi dan tingkat efisiensi biaya produksi pupuk organik berbahan dasar sisa media budidaya BSF menggunakan analisis $R / C$ ratio. Metode penelitian yang digunakan adalah studi kasus pada kelompok masyarakat di Kecamatan Cipedes Kota Tasikmalaya sejak tahun 2018. Hasil penelitian menunjukkan bahwa harga pokok produksi dari sisa media budidaya BSF adalah Rp14.663,00 dan hasil analisis R/C rasio adalah 1,40 menunjukkan bahwa penggunaan biaya pada proses produksi pupuk organik dari limbah media budidaya BSF sudah efisien.
\end{abstract}

Kata kunci: efisiensi biaya, lalat tentara hitam (BSF),limbah organik, pupuk organik

\begin{abstract}
Availability of organic waste has attracted the community as a business opportunity to utilize organic waste. One of the uses of organic waste that is carried out is as a growing medium and feed in the cultivation of black soldier fly (BSF) or maggot feed which at the end of the period there is residual cultivation media in the form of organic material that has the potential to be used as organic fertilizer. Organic fertilizer is an alternative to the use of organic waste that can be produced from the rest of the black army fly (BSF) cultivation media. The purpose of this study was to measure the cost of production and the level of efficiency of production costs of organic fertilizer based on residual BSF cultivation media using $R / C$ ratio analysis. The research method used is a case study on community groups in Cipedes District, Tasikmalaya City since 2018. The results showed that the cost of production of the remaining BSF cultivation media is Rp. 14,663.00 and the results of the $R / C$ ratio analysis are 1.40 , indicated that the used of costs in the production process of organic fertilizer from waste of BSF cultivation media is efficient.
\end{abstract}

Keywords: BSF, cost efficiency, organic waste, organic fertilizer

\section{PENDAHULUAN}

Kota Tasikmalaya menjadi kota pemekaran yang berkembang menjadi pusat pertumbuhan ekonomi di wilayah

$\begin{array}{lcr}\text { priangan timur Jawa Barat. } & \text { Sektor } \\ \text { pertanian } & \text { mendominasi } & \text { menjadi } \\ \text { penopang perekonomian di } & \text { Kota } \\ \text { Tasikmalaya. } & \text { Pengembangan } & \text { kondisi }\end{array}$


Kota Tasikmalaya mengakibatkan munculnya persoalan dalam pelayanan prasarana perkotaan, salah satunya adalah masalah timbunan sampah. Menurut data, timbunan sampah per kapita di Kota Tasikmalaya berada pada kisaran 3,63 Liter/orang/hari atau $0,44 \mathrm{~kg} /$ orang/hari (Dinas Lingkungan Hidup, 2017). Hal tersebut tidak menutup kemungkinan timbulnya permasalahan dalam mengatasi banyaknya limbah, serta memiliki tantangan tersendiri dalam pengelolaan limbah tersebut.

Melimpahnya ketersediaan limbah di Kota Tasikmalaya memunculkan pandangan baru dari masyarakat, yaitu sebagai peluang usaha dengan melakukan pemanfaatan limbah. Limbah plastik atau limbah anorganik lainnya sudah banyak diolah menjadi kerajinan tangan dan juga sebagian diolah menjadi bahan daur ulang. Sementara itu limbah organik yang juga cukup melimpah jusru menarik sebagian masyarakat untuk memanfaatkan atau mengolahnya. Salah satu pemanfaatan limbah organik tersebut yang tengah dilakukan saat ini antara lain dengan mengolahnya sebagai media tumbuh serta pakan dalam budidaya lalat tentara hitam (Black Soldier Fly /BSF) atau yang terkenal juga dengan istilah pakan maggot yang berpotensi sebagai substitusi maupun pelengkap protein tambahan pakan ternak. Gabler (2014) menyatakan bahwa pemanfaatan BSF sebagai strategi pengelolaan limbah/sampah organik merupakan strategi inovatif karena dapat menghasilkan pupuk organik sekaligus pakan ternak yang mengandung lemak dan protein yang melimpah.

Pada akhir periode budidaya BSF terdapat sisa media budidaya berupa bahan organik yang dapat berpotensi dijadikan sebagai bahan pupuk organik. Bahan organik bekas media maggot ini bahkan lebih bagus dari bahan organik yang lain karena mengandung protein tinggi. Menurut Kartini (2018), pembuatan pupuk organik bekas media pertumbuhan larva BSF sangat dipengaruhi oleh jenis media yang digunakan, karena dengan media yang lebih tepat akan menghasilkan kualitas pupuk organik yang lebih baik. Pupuk organik memiliki kelebihan yakni selain mampu meningkatkan sifat kimia tanah juga sekaligus dapat meningkatkan kualitas fisik dan biologi tanah. Kesadaran petani untuk mengkombinasikan pupuk anorganik dengan pupuk organik saat ini sudah muncul bahkan sudah terbiasa. 
Bahan organik bekas media pertumbuhan larva BSF dapat menjadi salah satu tambahan masukan selain dari pakan maggot. Namun penambahan output tersebut belum diketahui secara pasti mengenai harga pokok produksi serta tingkat efisiensi produksi yang dihasilkan dari sisa bekas media pertumbuhan maggot. Pengukuran efisiensi untuk menjalankan sebuah sistem produksi sangat penting dilakukan, salah satunya adalah jika perencanaan yang berkaitan dengan ekonomi atau biaya dengan sebuah sistem produksi tertentu, maka penting untuk mengetahui seberapa jauh suatu sistem produksi dapat meningkatkan output dengan meningkatkan efisiensi tanpa perlu menyerap sumber daya lebih lanjut (Farrel, 1957).

\section{METODE PENELITIAN}

Penelitian dilakukan di kelompok masyarakat wilayah Kecamatan Cipedes yang melakukan aktivitas pemanfaatan limbah organik dalam budidaya BSF atau maggot serta mengolah limbah media BSF tersebut menjadi pupuk organik. Penelitian dilakukan secara sengaja (purposive), dengan waktu penelitian dilaksanakan pada bulan Mei sampai November 2021.
Analisis efisiensi pada pupuk organik berbahan dasar sisa media budidaya BSF menggunakan analisis $\mathrm{R} / \mathrm{C}$ ratio dengan rumus sebagai berikut:

$$
\mathrm{a}=\mathrm{R} / \mathrm{C}=(\mathrm{Py} . \mathrm{Y}) /(\mathrm{FC}+\mathrm{VC})
$$

Keterangan :

a : Tingkat Efisiensi biaya produksi

$\mathrm{R}$ : Penerimaaan (Rp)

C : Biaya produksi (Rp)

Py : Harga jual $(\mathrm{Rp} / \mathrm{Kg})$

Y : Jumlah produksi $(\mathrm{Kg})$

FC : Biaya Tetap (fixed cost) (Rp)

VC : Biaya Variabel (variable cost) (Rp)

Berdasarkan hasil perhitungan tersebut selanjutnya dianalisis menggunakan kriteria sebagai berikut: (a) jika nilai a $>1$, maka usaha produksi pupuk organik dikatakan efisien dan (b) jika nilai a $<1$, maka usaha produksi pupuk organik dikatakan tidak efisien

\section{HASIL DAN PEMBAHASAN}

Analisis efisiensi produksi digunakan untuk menentukan usaha yang dilakukan efisien atau tidak efisien. Noer dkk (2018) menyatakan bahwa analisis efisiensi produksi dilakukan dengan cara menghitung efisiensi ekonomi, efisiensi teknis dan harga (alokatif). Keadaan dikatakan efisiensi ekonomi jika usaha pertanian tersebut mencapai efisiensi teknis dan efisiensi harga. Selain itu, 
efisiensi produksi juga dapat dilakukan dengan cara menghitung efisiensi biaya produksi (Suryandari dan Hapsari, 2020). Soekartawi (2003) menyatakan bahwa terdapat kegunaan mengukur efisiensi diantaranya adalah (1) sebagai tolok ukur untuk memperoleh efisiensi relatif, sehingga memudahkan untuk melakukan perbandingan antara unit ekonomi satu dengan lainnya, (2) apabila terdapat variasi tingkat efisiensi dari beberapa unit ekonomi yang ada, maka dapat dilakukan penelitian untuk menjawab faktor-faktor yang mempengaruhi perbedaan tingkat efisiensi, dan (3) informasi mengenai tingkat efisiensi dapat memberikan implikasi kebijakan secara tepat.

Pembuatan pupuk organik bekas media pertumbuhan larva lalat tentara hitam (Hermetia illucens) sangat dipengaruhi oleh jenis media yang digunakan karena dengan media yang tepat akan menghasilkan kualitas pupuk organik yang lebih baik (Kartini, 2018). Residu sampah yang dihasilkan dari bekas media pertumbuhan larva lalat tentara hitam digunakan dalam pemenuhan kebutuhan pupuk organik (kompos) sehingga dapat mendorong tumbuhnya bisnis pertanian (Gabler, 2014; Alvarez, 2012; Dortmans, et al., 2017).

\section{Biaya Produksi}

Pupuk organik yang dihasilkan dari sisa media pertumbuhan larva lalat tentara hitam dapat digunakan dalam pemenuhan kebutuhan pupuk organik (kompos) dan tambahan pendapatan bagi produsen pakan maggot. Hasil penelitian Hanafie (2010) menyebutkan bahwa efisiensi merupakan ukuran yang menunjukkan suatu sumber daya ekonomi digunakan dalam proses produksi untuk menghasilkan output. Dalam proses produksi, diperlukan beberapa biaya yang harus dikeluarkan, yaitu biaya tetap, biaya bahan baku dan tenaga kerja. Berikut Tabel 1 rincian biaya tetap produksi pupuk organik dari limbah media budidaya BSF.

Berdasarkan pada Tabel 1 menunjukkan biaya tetap yang dikeluarkan untuk proses produksi pupuk dari limbah media budidaya BSF, biaya terbesar yang dikeluarkan adalah penggunaan biopond sebagai wadah atau tempat pertumbuhan larva BSF yaitu sebesar 67,11 persen. Dalam proses budidaya sekaligus proses produksi pupuk dari sisa media budidaya BSF, biopond menjadi komponen yang sangat penting untuk digunakan. Biopond yang digunakan terbuat dari papan kayu dan bagian bawahnya menggunakan triplek 
serta diperkuat dengan penggunaan semen dan diberi alas plastik. Jumlah biopond yang digunakan akan mempengaruhi output yang dihasilkan, termasuk pada sisa media budidaya BSF. Oleh karena itu, penggunaan biaya biopond memiliki persentase yang paling tinggi, diikuti dengan penggunaan bak plastik, sebagai wadah atau penampungan sisa media pertumbuhan larva BSF.

Tabel 1. Rincian Biaya Tetap Produksi Pupuk Organik Dari Limbah Media Budidaya BSF

\begin{tabular}{|c|c|c|c|c|}
\hline No & Peralatan & Jumlah & $\begin{array}{c}\text { Total } \\
\text { Biaya } \\
(\mathrm{Rp})\end{array}$ & $\begin{array}{c}\text { Penyu- } \\
\text { sutan } \\
\text { (Rp) }\end{array}$ \\
\hline 1 & Bak Plastik & 24 buah & 600.000 & 25.000 \\
\hline 2 & $\begin{array}{l}\text { Plastik alas } \\
\text { biopond }\end{array}$ & 10 meter & 150.000 & 6.250 \\
\hline 3 & Cukil tanah & 2 buah & 10.000 & 1.667 \\
\hline 4 & $\begin{array}{l}\text { Wire } \\
\text { mesh/ayakan }\end{array}$ & 2 buah & 20.000 & 6.667 \\
\hline 5 & Biopond & 10 unit & 2.000 .000 & 83.333 \\
\hline 6 & Naungan & 10 meter $^{2}$ & 200.000 & 8.333 \\
\hline \multicolumn{3}{|c|}{ Total Biaya } & 2.980 .000 & 131.250 \\
\hline
\end{tabular}

Berdasarkan pada Tabel 2 menunjukkan penggunaan biaya variabel dalam satu kali proses produksi pupuk dari limbah media budidaya BSF yang memperlihatkan bahwa total biaya variabel adalah sebesar Rp1.261.000,00. Persentase penggunaan input terbesar yaitu pada biaya kebutuhan larva BSF yaitu sebesar 59,48 persen. Larva BSF menjadi salah satu variabel atau input penting yang digunakan dalam proses produksi pupuk organik dari limbah media budidaya BSF. Hal ini terjadi, karena larva BSF memiliki fungsi sebagai pereduksi atau menguraikan sampah organik baik dari hewan, tumbuhan, maupun dari kotoran hewan serta kotoran manusia sebagai bahan makannya dan meningkatkan nilai daur ulang dari sampah organik. Berikut Tabel 2 rincian biaya variabel produksi pupuk organik dari limbah media budidaya BSF.

Tabel 2. Rincian Biaya Variabel Produksi Pupuk Organik Dari Limbah Media Budidaya BSF

\begin{tabular}{rlrcrc}
\hline No & Peralatan & Jumlah & Satuan & $\begin{array}{c}\text { Harga } \\
\text { (Rp/satuan) }\end{array}$ & $\begin{array}{c}\text { Total } \\
\text { Biaya } \\
\text { (Rp) }\end{array}$ \\
\hline 1 & Limbah Kotoran Hewan & 3 & karung & 17.000 & 51.000 \\
2 & Limbah Sayur dan Buah & 3 & karung & 50.000 & 150.000 \\
3 & Limbah Restoran & 3 & karung & 50.000 & 150.000 \\
4 & Larva BSF & 50 & gram & 15.000 & 750.000 \\
5 & Tenaga Kerja & 2 & orang & 80.000 & 160.000 \\
\hline Total Biaya Variabel & & & & 1.261 .000 \\
\hline
\end{tabular}

Sumber: Analisis Data Primer (2021)

Selanjutnya berdasarkan pada

Tabel 2, terdapat tiga jenis limbah yang digunakan dalam proses produksi pupuk organik dari sisa media pertumbuhan larva BSF, yaitu limbah kotoran hewan, limbah sayuran dan buah, serta limbah restoran, sehingga terdapat biaya yang perlu dikorbankan dalam memperoleh limbah tersebut, termasuk biaya tenaga kerja. Dalam pengadaan bahan baku larva BSF yang digunakan berasal dari peternak BSF serta media pertumbuhan larva BSF diperoleh dari pasar, restoran, serta peternak ayam. Berikut rincian biaya dan persentase produksi pupuk organik dari limbah media budidaya BSF. 
Tabel 3. Rincian Biaya dan Persentase Produksi Pupuk Organik Dari Limbah Media Budidaya BSF

\begin{tabular}{clrr}
\hline No. & Kebutuhan Biaya & Total Biaya (Rp) & Persentase (\%) \\
\hline 1 & Biaya Tetap & & \\
& Biaya Penyusutan Alat & 131.250 & 9,43 \\
2 & Biaya Variabel & & \\
& Bahan Baku & 1.101 .000 & 79,08 \\
& Biaya Tenaga Kerja & 160.000 & 11,49 \\
\hline Total Biaya & 1.392 .250 & 100 \\
\hline
\end{tabular}

Sumber: Analisis Data Primer (2021)

Berdasarkan pada Tabel 3 memperlihatkan bahwa biaya biaya tetap lebih kecil dibandingkan dengan biaya variabel. Hal ini menunjukkan bahwa biaya investasi pada produksi pupuk organik dari limbah media budidaya BSF memiliki pengembalian modal yang lebih cepat. Hasil penelitian ini sejalan dengan Fitasari, dkk (2017) bahwa biaya investasi pada Unit Pengelola Pupuk Organik (UPPO) Tani Mandiri I B lebih kecil dibandingkan dengan biaya variabelnya yang menunjukkan pengembalian modal yang akan lebih cepat.

\section{Efisiensi Biaya Produksi}

Pupuk organik yang dihasilkan sebagai sisa media pertumbuhan larva BSF menjadi input tambahan dalam budidaya BSF. Namun jumlah pupuk organik yang dihasilkan ini memiliki jumlah yang berbeda-beda dari setiap limbah media pertumbuhan yang digunakan. Hal ini dikarenakan larva BSF memiliki kemampuan melakukan reduksi yang berbeda pada setiap limbah media pertumbuhan yang digunakan. Sejalan dengan penelitian yang dilakukan Zakova dan Borkovcova (2013) menyebutkan bahwa larva BSF dapat mereduksi sampah rumah tangga (makanan, sisa sayuran, dan buah) dan sampah kebun hingga 64 persen dalam skala laboratorium. Tingkat reduksi larva BSF untuk limbah kotoran ayam sekitar 50 persen (Mahardika, 2016).

Perbedaan kemampuan reduksi larva BSF terhadap limbah media pertumbuhan yang dilakukan akan mempengaruhi jumlah pupuk organik yang dihasilkan. Pada penelitian ini, jumlah pupuk organik yang dihasilkan sebanyak 94,50 kilogram. Berikut Tabel 4 merupakan analisis efisiensi produksi pupuk pupuk organik dari limbah media budidaya BSF.

Tabel 4. Analisis Efisiensi Biaya Produksi Pupuk Organik Dari Limbah Media Budidaya BSF

\begin{tabular}{clcr}
\hline No. & \multicolumn{1}{c}{ Uraian } & Satuan & \multicolumn{1}{c}{ Total } \\
\hline 1 & Penerimaan (R) & $\mathrm{Rp}$ & 1.946 .475 \\
2 & Biaya Total (C) & $\mathrm{Rp}$ & 1.392 .250 \\
& Biaya Tetap & $\mathrm{Rp}$ & 131.250 \\
& Biaya Variabel & $\mathrm{Rp}$ & 1.261 .000 \\
3 & HPP (Harga Pokok Produksi) & $\mathrm{Rp}$ & 14.663 \\
4 & Pendapatan & $\mathrm{Rp}$ & 554.225 \\
5 & R/C rasio & $\mathrm{Rp}$ & 1,40 \\
\hline
\end{tabular}

Sumber: Analisis Data Primer (2021)

Efisiensi biaya proses produksi pupuk organik dapat diketahui dengan membandingkan penerimaan yang diperoleh dari proses penjualan pupuk organik dengan total biaya yang dikeluarkan oleh produsen yang terdiri 
atas biaya tetap dan biaya variabel. Berdasarkan pada Tabel 4 menunjukkan total biaya dalam satu kali produksi proses pupuk organik yaitu Rp1.392.250,00. Penerimaan yang diperoleh yaitu sebesar Rp1.946.475,00. Total penerimaan diperoleh dari harga jual pupuk organik yaitu Rp20.500,00 per kilogram dengan jumlah pupuk organik yang dihasilkan adalah sebesar 94,95 kilogram keseluruhan dari total kasgot limbah kotoran hewan (ayam petelur), limbah restoran, serta limbah sayur dan buah.

Tabel 4 memperlihatkan bahwa harga pokok produksi (HPP) dari pupuk organik yang dihasilkan adalah sebesar Rp14.663,00 per kilogram, sehingga keuntungan atau pendapatan yang diperoleh dalam satu kali proses produksi adalah Rp554.255,00. Dalam pengukuran efisiensi digunakan analisis $\mathrm{R} / \mathrm{C}$ ratio yaitu dengan membandingkan antara penerimaan dan biaya produksi yang dikeluarkan. Selanjutnya hasil analisis $\mathrm{R} / \mathrm{C}$ rasio menunjukkan hasil 1,40 yang memiliki arti bahwa setiap pengeluaran biaya sebesar Rp1,00 akan menghasilkan penerimaan sebesar Rp1,40. Nilai koefisien dari $\mathrm{R} / \mathrm{C}$ rasio menunjukkan angka lebih dari satu $(>1)$, sehingga dapat disimpulkan bahwa penggunaan biaya pada proses produksi pupuk organik dari limbah media budidaya BSF sudah efisien.

\section{KESIMPULAN DAN SARAN}

Berdasarkan pada penelitian yang telah dilakukan pada efisiensi biaya produksi pupuk organik berbahan dasar limbah media budidaya lalat tentara hitam (Hermetia illucens), hasil analisis $\mathrm{R} / \mathrm{C}$ rasio menunjukkan hasil 1,40 . Nilai koefisien dari $\mathrm{R} / \mathrm{C}$ rasio menunjukkan angka lebih dari 1, sehingga dapat disimpulkan bahwa penggunaan biaya pada proses produksi pupuk organik dari limbah media budidaya BSF sudah efisien.

Diharapkan melalui penelitian ini dapat menjadi gambaran bagi pelaku usaha dalam melakukan budidaya BSF dan produksi pupuk organik dari sisa media pertumbuhan larva BSF, bahwa terdapat tambahan masukan yang efisien dan menguntungkan dari pupuk organik yang dihasilkan.

\section{UCAPAN TERIMA KASIH}

Penulis mengucapkan terima kasih kepada Universitas Siliwangi atas dana Penelitian Dosen Pemula tahun anggaran 2021 dan kelompok masyarakat wilayah Kecamatan Cipedes, Kota Tasikmalaya 
yang telah memberikan kesempatan dan izin untuk melakukan penelitian.

\section{DAFTAR PUSTAKA}

Alvarez, L. 2012. The Role of Black Soldier Fly, Hermetia illucens (L.) (Diptera: Stratiomyidae) in Sustainable Waste Management in Northern Cimates. University of Windsor.

Dinas Lingkungan Hidup. 2017. Kajian Perhitungan Timbulan Sampah. 274 Tasikmalaya.

Dortmans, B., Diener, S., Verstappen, B., dan Zurbrugg, C. 2017. Black Soldier Fly (BSF) Biowaste Processing - A Step-by-Step Guide Eawag: Swiss Federal Institute of Aquatic Sciance and Technology (P. Donahue Ed). Switzerland: Departement od Sanitation, Water and Solid Waste for Development (Sandec).

Farrel, M, J. 1957. The measurement of productive efficiency. Journal of The Royal Start. Societty, Series A (120) : 253 - 290.

Fitasari, Fiky, Triana Dewi Hapsari, dan Ebban Bagus Kuntadi. 2017. Efisiensi Biaya Produksi Pupuk Organik Pada Unit Pengelola Pupuk Organik (UPPO) Tani Mandiri I B Di Desa Lombok Kulon Kecamatan Wonosari Kabupaten Bondowoso. Jurnal Agribisnis Indonesia, Vol. 5 No.1, Juni 2017 [11-26].

Gabler, F. 2014. Using Black Soldier Fly For Waste Recycling And Effective Salmonella Spp. Reduction. Theses. Swedish University of Agricultural Sciences, Swedish

Hanafie, Rita. 2010. Pengantar Ekonomi Pertanian. Yogyakarta: CV. Andi Offset.
Hardini, Sri Yuniarti Putri Koes dan Abel Gandhy. 2020. Analisis Harga Pokok Produksi Usaha Budidaya Larva Black Soldier Fly (Hermetia illucens) Skala Rumah Tangga. Seminar Nasional Virtual Politeknik Pertanian Negeri Payakumbuh.

Kartini, L.N. 2018. Pengaruh Cacing Tanah Dan Jenis Media Terhadap Kualitas Pupuk Organik. Jurnal Agroekoteknologi Tropika. 8(1): 49-53

Mahardika, Tifani Rosa. 2016. Teknologi Reduksi Sampah Dengan Memanfaatkan Larva Black Soldier Fly (BSF) Di Kawasan Pasar Puspa Agro Sidoarjo. Surabaya: Institut Teknologi Sepuluh November.

Noer, Suci Rodian., Wan Abbas Zakaria, dan Ktut Murniati. 2018. Analisis Efisiensi Produksi Usahatani Padi Ladang di Kecamatan Sidomulyo Kabupaten Lampung Selatan. Jurnal Ilmu-Ilmu Agribisnis (JIIA), Vol. 6 No.1 (17-24)

Suryandari dan Hapsari. 2020. Efisiensi biaya produksi pupuk organik padat (POP) pada PT. Sirtanio Organik Indonesia. Jurnal Ekonomi Pertanian dan Agribisnis (JEPA). 4(1): 13-25.

Soekartawi. 2003. Teori Ekonomi Produksi Dengan Pokok Bahasan Analisis Fungsi Cobb-Douglass. Cetakan Ketiga. Jakarta: Rajawali Pers.

Zakova, M dan Borkovcova, M. 2013. Comparison of Field and Lab Application of Hermetia illucens Larvae. Journal Mendelnet Department of Zoology, Fisheries, Hydrobiology dan Apliculture, Faculty of Agronomy, Mendel University in Brno, Zemedelska, 1:613 00 Brno. 